\title{
Historical Lessons for Australia's Foreign Policy: The Case of British EEC Membership
}

\author{
Nina Markovic Khaze \\ Visiting Fellow \\ Centre for European Studies, Australian National University \\ nina.markovic@anu.edu.au \\ missninamar@gmail.com
}

\begin{abstract}
The Australian Government's attitudes towards major events in international politics such as the UK's entry into the European Economic Community (EEC) in the past and Brexit negotiations today, carry greater weight than previously assumed in political science literature. Australia was critical of the EEC (now called the European Union, EU) in the early 196os, when its then most important trading partner, the United Kingdom (UK) first applied for membership. Australia was ill-prepared to deal with the repercussions from Britain's entry into the EU, as Australian foreign policy was heavily influenced by local as well as international anti-EEC attitudes. This paper will analyse political debates in Australia during the 1960 s and early 1970 s with reference to parliamentary Hansard records and newspaper articles in order to suggest a new framework for Australian foreign policy analysis.
\end{abstract}

Keywords: Australian foreign policy, Australia-United Kingdom relations, Brexit, the Commonwealth

\section{Introduction}

This paper argues that the future of Australia's relations with the EU-27 and Great Britain in particular, as in the 1960s and 1970s, will be closely related to Australia's efforts to prepare its citizens for Brexit. Issues of immigration, trade and identity politics are currently high on the Australian Government's agenda when dealing with these interlocutors, as are discourses related to domestic politics. The Australian Government's efforts to conclude and ratify Free Trade Agreements (FTA) with the EU and the UK (which fall within the Coalition Government's broader agenda that pushes for FTAs globally) would need to be supplemented with a clear and publicly available strategy for Australian citizens to deal with emerging issues before Brexit negotiations are concluded. Protecting Australian interests abroad is, after all, a major aim of Australian foreign policy. Failure to do so might produce a similar result to that of the mid-1970s when it became evident that the Australian Government's one-sided strategy (of lobbying against UK's membership) directly damaged Australian primary export industries, many of which never fully recovered.

One possible explanation for Australia's failure to prepare its export industry for an alternative policy scenario has been the belief of Australia's major political parties that 
the close and 'special' relationship between the UK and Australia during the 1960s, as well as Australia's international lobbying against UK's EEC membership, would counter any negative consequences. This was not the case in reality. Another possible explanation is that the political bickering resulting from a very contentious election year in Australia, which was also the year in which Britain concluded its EEC membership negotiations (1972), distracted both the Australian electorate and public service from focusing on the domestic consequences from events in the international political realm. This paper aims to expand the knowledge of what political scientist Robert Putnam calls a 'two-level game' by national governments, which try to cater for the international realm, whilst focusing on domestic audiences in their discourses, including in the foreign policy realm. ${ }^{1}$

\section{Domestic politics as a 'distraction' for the foreign policy realm}

The Federal Government's short-sighted policy in the 1960s of pursuing its preferred policy rhetoric rather than of preparing for a potentially opposite outcome, harmed the prospects of the Australian export industry in relation to the UK's successful bid to join the European Economic Community (EEC). The Government's stubborn anti-EEC attitude may have misled the public by not appropriately dealing with the potential loss of Australia's largest export market at a policy level, even when it became increasingly evident that the UK was on the path of joining Denmark and the Republic of Ireland to attain EEC membership. The 1960s was an era in Australian political history when Canberra and London co-operated closely on trade, defence and security matters, but drifted apart in their respective foreign policy outlooks towards Western European integration.

UK membership of the EEC from 1 January 1973, therefore, brought about a radical transformation of Australia's international outlook. It represented a profound and uncomfortable shock for most Australians. ${ }^{2}$ This single event influenced negative attitudes of Australian policy-makers and diplomats towards the EEC for many years to come. However, this rude awakening coincided with a major change in Australia's domestic political landscape which distracted the government and prevented a viable response to a major international development. Only a month earlier Gough Whitlam led the Australian Labour Party to victory after the Liberal Party's unbroken twentytwo year reign. Although various Australian export industries had at least a decade to prepare for the eventuality of the UK's success in acquiring membership of the EEC, the Federal Government's failure to deal with that scenario at the policy level had negative repercussions. One immediate consequence was a huge drop in exports and the loss of revenue which burdened both the Australian Government and export industry for many years afterwards. Another consequence was an acrimonious relationship with the expanded EEC, particularly in the area of agriculture and international trade negotiations. This paper argues that there are some major lessons to be learned from that historical period for Australian foreign policy analysis. Australia may again lose out in the current period of Brexit negotiations unless it prepares through reform and improved foreign policy foresight.

\footnotetext{
${ }^{1}$ Putnam, Robert. 'Diplomacy and Domestic Politics: The Logic of Two-Level Games'. International Organization 42 (1988): 427-460.

${ }^{2}$ The first major change in Australia's post-war foreign policy was the forging of the ANZUS alliance with the United States of America and New Zealand in 1951, which confirmed the primacy of the United States as Australia's principal ally in wartime. This shifted the primary focus of Australian defence policy from the UK to the US.
} 


\section{First British EU application (1961) and Australian political discourses}

On 19 March 1957, the then Governor-General of Australia, Sir William J. Slim, cautioned about protectionist consequences for Australia from a nascent European supra-national project, which was to become the European Community:

Over the past year ... the six countries of the European coal and steel community have carried forward their plans for the formation of a customs and economic union. The United Kingdom has entered upon negotiations for a free trade area which would bring her, and perhaps other countries of Europe, into association with the common market of the six. Such far-reaching changes could have important implications for the Australian economy and these developments are being kept under close review. 3

Yet even though the top tier of Australian policy-makers was alarmed by the prospect of a British EEC application, no structural adjustment took place in foreign and trade policy orientation for a good part of the next decade. The UK Government first applied for membership in the European Economic Community only three years after Harold Macmillan, the first serving British Prime Minister ever to visit Australia, reaffirmed the strength of bilateral relations between Australia and the UK. During his visit, a new social services agreement was concluded, which entered into force on 1 April 1958. This was important as Australia launched the post-war 'Bring-a-Briton' assisted immigration scheme, which meant that growing numbers of UK citizens were moving to Australia, and social services was an important aspect of bilateral relationship. During Macmillan's visit, the Governor-General of Australia stated:

The visit of the RH Harold Macmillan ...has evidenced and strengthened our practical unity with the United Kingdom. ...While our ties with the United Kingdom, and with the Commonwealth of Nations, have been strengthened, we have demonstrated further our neighbourly interest in Asian development. 4

At that time, Australia and the UK cooperated closely in the defence sector, with Australia offering, as a matter of then top-secret intelligence, terrain for the UK's testing of nuclear weapons from 1952 to $1963 .{ }^{5}$ Furthermore, despite Australia's emerging interest in developing closer ties within its neighbours (as demonstrated in the aforementioned quote) Australia's political, economic and industry leaders were dismayed when the British formally applied for membership in the six-nation European Community. British Prime Minister Harold Macmillan announced this decision on 31 July 1961 in the House of Commons. ${ }^{6}$ The Australian Prime Minister, Robert Menzies, recognised the significance of the British decision to apply for EEC membership. After visiting London in mid-1962, Menzies observed that Australian

\footnotetext{
3 Australian Parliament, ‘Governor-General's speech', 19 March 1957, House Hansard, Commonwealth of Australia,

http://parlinfo.aph.gov.au/parlInfo/search/display/display.w3p;query=Id\%3A\%22hansard80\%2Fhansardr80\%2 F1957-03-19\%2Fo010\%22 (accessed online 21 June 2017).

4 House of Representatives, 'Governor-General's speech', 25 February 1958, pp. 1, 4, http://parlinfo.aph.gov.au/parlInfo/search/display/display.w3p;query=Id\%3A\%22hansard80\%2Fhansardr8o\%2 F1958-02-25\%2F0024\%22 (accessed online 20 June 2017).

5 National Museum of Australia, 'Robert Menzies', http://www.nma.gov.au/primeministers/robert_menzies (accessed online 20 June 2017).

6 'U.K. decision on negotiations: Common Market entry sought', Canberra Times, 1 August 1961, p. 1.
} 
exports most likely to suffer as a result of the UK's EEC accession were sugar, lead, dairy products, meat, dried fruits and canned fruit. ${ }^{7}$ This demonstrates that the Australian top decision-makers were well-aware of the dangers to the Australian economy, yet did little to initiate a transition process. Their one-sided, anti-EEC and pro-imperial attitudes and rhetoric may well have impeded the transition.

At the September 1962 Commonwealth Heads of Government meeting, Menzies joined other Commonwealth leaders in expressing his displeasure with the British decision. Menzies believed that the Commonwealth nations would be weakened should the imperial preferences system between the UK and Commonwealth nations be abolished. ${ }^{8}$ His comments in late 1961 and the first half of 1962 regarding the British EEC application were carefully measured without open criticism, and intensified on the negative side only after he faced heavy domestic criticism for not being direct about the issue. ${ }^{9}$ This demonstrates that established domestic political practices, such as the general rule not to criticise the UK as a major partner in public, also played a role in the Australian Government's lack of preparation for the UK's potential EEC membership. Any such preparation could have been interpreted potentially as a sign of disloyalty towards the British.

Public statements by Menzies more openly questioning the British decision to join the EEC from the second part of 1962 onwards were at odds with the Prime Minister's previously stated position (in 1958) that Australia not disagree in public with the decisions made by its great and powerful friends:

Australia was an independent nation, but truly independent only in the legal sense as its security was bound up with the security of others and with their beliefs about Australia's goodwill and responsibility. ...But when you cannot live without your friends you do not argue with them or disagree with them in public. You resolve your differences in private. ${ }^{10}$

It was obvious that the stark differences between the UK and Australia on this issue would resound widely. From 1962 onwards, representations on Australia's behalf were made by many sectors of the Australian Government, parliamentary and business groups. An article from the Canberra Times of 1962 observed a developing crisis within the Federal Government's ranks on the issue of 'magnitude of the repercussions if Australia loses its British trade preferences'. ${ }^{11}$ Its first 'victim' was the Minister for Air, Les Bury, who was sacked in July 1962 following his comments which referred to 'exaggerated threats' for Australia if Britain was to join the EEC. ${ }^{12}$ His view deeply conflicted with that of the Leader of the then Country Party, Sir John McEwen, who was Minister for Trade and Industry. ${ }^{13}$ The Country Party was vehemently opposed to

\footnotetext{
7 'Menzies renews market warning', Canberra Times, 10 August 1962, p. 1. These fears were proven true as Australia's butter exports were slashed by 90 per cent in the years following British accession to the EEC. ${ }^{8}$ National Archives of Australia, 'Robert Menzies in office',

http://primeministers.naa.gov.au/primeministers/menzies/in-office.aspx (accessed online 20 June 2017).

${ }_{9}^{9}$ See, for example, E.W. Campbell, 'Menzies silent on sell out of Australia', Tribune, 29 November 1961, p. 10.

10 'Security first, says Menzies', Canberra Times, 31 July 1958, p. 3.

11 'Cabinet crisis on trade view conflict', Canberra Times, 27 July 1962, p. 1.

12 Ibid.

13 MP Ian Sinclair (Leader of the National Party of Australia), 'Death of Hon. L.H.E. Bury, CMG', Hansard, House of Representatives, No. 150, 1986, 16 September 1986,

http://parlinfo.aph.gov.au/parlInfo/search/display/display.w3p;query=Id\%3A\%22chamber\%2Fhansardr\%2F198 6-09-16\%2Fo010\%22 (accessed online 20 June 2017).
} 
the British EEC application as early as at 1961, but collectively these parties did little to inform industry about how best to prepare for the loss of the British market.

The Menzies Government became extremely sensitive about this issue as the time went on. ${ }^{14}$ The agricultural sector was particularly vulnerable to any changes in the Imperial Trade Preferences system for the Commonwealth countries, which above all accorded certainty to Australian producers in terms of market access and distribution channels. If the British were to join the EEC, the Australian Government officials argued, Australian businesses would be, as an immediate consequence, locked out of the EEC's trade market; lose special status in trading with the British, and consequently suffer financial losses that the government would have to compensate. However, the Government could have done much more to prepare industry for the UK's EEC entry and find new ways of trading and markets which eventually it had to do anyway but with grave consequences for many established exporters.

The Labor opposition also verbally argued against the British EEC application, but did little to suggest how this shift could be managed in practice. They offered no alternative policy on this issue. A member of the Australian Labor Party and Member of the House of Representatives for Blacktown, A. Dennis, for example said in the week leading up to the UK's formal application to join the EEC that 'Australia's standard of living would be threatened by any sudden stoppage of trade with Great Britain'. ${ }^{15}$ Some minor parties were also vocal on the issue of Britain's EEC application. Australia's Communist Party, which Prime Minister Menzies sought to ban (unsuccessfully), accused the Federal Government of compliance with the British to the detriment of national economic interests because of a geo-political agenda. ${ }^{16}$

Australia's top level government reluctance to voice its rejection of the British EEC application earlier on could be in part explained by its support for anti-communist drives globally and in Europe specifically, and the fact that successive U.S. administrations (under both the Eisenhower and Kennedy presidencies) were strongly supportive of the first British EEC application. ${ }^{17}$ The ANZUS alliance between Australia, the U.S. and New Zealand in 1951 was the cornerstone of Australia's postwar foreign policy and was Menzies' most important initiative. The Government's anticommunist drive in foreign policy that followed alliance commitments, therefore, was also partly responsible for Australia's real lack of preparation for British EEC membership.

By the spring of 1961, as academics Deighton and Ludlow argue, 'the Americans had bluntly informed the British' that they should try to join the EEC and 'help to create a united Western Europe' against growing influence of the Communist regimes. ${ }^{18}$ This was taking place at the time of growing tensions between the West and the Soviet Union over the status of military forces in West Berlin, amongst other contentious

\footnotetext{
14 By contrast, Australia is today criticised in Europe for voicing what it seems like an enthusiasm for forging a new trade deal with the UK. Australia's foreign policy pragmatism is at display here and government will need to engage in negotiations with both the EU and the UK concurrently.

15 'Warns on trade plans', Cumberland Argus, 26 July 1961, p. 7.

16 'Security first, says Menzies', op. cit.

17 'Headaches in the Common Market', Tribune, 21 June 1961, page 2.

18 Anne Deighton and Piers Ludlow, 'A conditional application': British management of the first attempt to seek membership of the EEC, 1961-3', in Building postwar Europe. National decision-makers and European institutions 1948-63, Anne Deighton (ed.), pp. 107-126, UK, Palgrave Macmillan, 1995.
} 
issues. ${ }^{19}$ The UK's opposition Labour Party leader, Hugh Gaitskell, in 1962 'called for a general election before any decision is made' on EEC membership. ${ }^{20}$ France under President Charles de Gaulle rejected the first British application in $1963 .{ }^{21}$ Australians rejoiced at this outcome; however, only four years later the British submitted their second application to join the EEC, which was also rejected by the French. Despite having twelve years to adjust, Australia remained ill-prepared for the eventual British entry into the EEC (alongside Denmark and Ireland) on 1 January 1973. The Federal Government relied on a preferred foreign policy outcome rather than changes in the international system. This shows a failure in policy-making and a dangerous delay in Australia's response to changes in the international system and regional integration in Europe more specifically.

\section{Further British EEC applications and accession in 1973}

Nevertheless, when Britain applied again to join the EEC on 2 May 1967, Australian policy makers were still dismayed but somewhat better prepared to address this issue on several fronts. In 1967, Australia was deeply engaged in trade discussions with Japan and the EEC, seeking better market access for its agricultural products (including meat, canned and dairy), and primary commodities (such as coal and iron ore), and in multilateral trade discussions during the U.S.-driven Kennedy round of the General Agreement on Tariffs and Trade (GATT) negotiations. ${ }^{22}$ By that time, Australia had already established an embassy in Brussels, led by its first Ambassador to the EEC, Sir Edwin McCarthy, an experienced trade negotiator and diplomat who served in Brussels until $1964 .^{23}$ Menzies was no longer Prime Minister, having resigned in 1966 after sixteen continuous years in office. ${ }^{24}$ Despite the attempts to establish relations with the EEC, in all international trade forums Australia represented itself as a victim of the British EEC application, and argued ardently against the prospect of its success.

By 1967, the EEC had also gained competency as an international trade actor, having secured access for many of its members' products, including dairy, in Southeast Asia. The EEC had, by then, become a serious rival to Australia's commercial interests in the Asia-Pacific region. It was unsurprising, if unwise, that Australia's Minister for Trade and Industry, John McEwen, had criticised the new British application for EEC membership at every available opportunity. ${ }^{25}$ Australian policy-makers' anti-EEC

\footnotetext{
19 'The Berlin Crisis: 1958-1961', U.S. Office of the Historian, Department of the State, Government of the United States of America, https://history.state.gov/milestones/1953-1960/berlin-crises (accessed online 20 June 2017). 20 'Menzies in Common Market hoax', Tribune, 26 September 1962, page 12.

${ }^{21}$ Internal divisions in the UK over the EEC were evident even earlier when the British firstly committed a representative to the Messina conference in June 1955, which initiated moves towards the customs union, but then the British withdrew. 'The EEC and Britain's late entry', The UK National Archives,

http://www.nationalarchives.gov.uk/cabinetpapers/themes/eec-britains-late-entry.htm (accessed online 21 June 2017).

22 'Address by J. McEwen (Acting Prime Minister and Minister for Trade and Industry) at National press club luncheon', 1 June 1967,

http://parlinfo.aph.gov.au/parlInfo/search/display/display.w3p;query=Id\%3A\%22media\%2Fpressrel\%2FHPR10 002915\%22 (accessed online 21 June 2017).

23 Prior to his Ambassadorial appointment, McCarthy was the Chairmen of the International Wheat Council, and in one of his previous roles held the post of Deputy High Commissioner to London. Australian Dictionary of Biography, 'Sir Edwin McCarthy', Australian National University, http://adb.anu.edu.au/biography/mccarthy-siredwin-10909 (accessed online 21 June 2017).

${ }^{24} \mathrm{He}$ retired from politics to allow new generations to lead, with Harold Holt becoming Australia's next Prime Minister (whose term was cut short by his disappearance and presumed drowning in December 1967).

${ }^{25}$ See, for example, 'Concern on British interest in Market', The Age, 13 August 1966; 'Danger to Australia seen in U.K. Market move', 25 October 1966, Daily Telegraph (no page numbers provided)
} 
attitude permeated almost every discussion on this topic and dominated Australia's trade agenda that showed no significant signs of maturing until quite late in the 1960 s.

The UK frequently held sectoral consultations with the Commonwealth countries on the implications of the British EEC application. On one such occasion during consultations on the Commonwealth Sugar Agreement, McEwen praised the British Prime Minister for specifically mentioning the safeguarding of interests of the Commonwealth countries in his speech to the House of Commons when he announced the UK's second application for EEC membership. ${ }^{26}$ This seemed to be at odds both with the EEC's integrationist agenda and showed a lack of full-hearted commitments by the British to embrace change.

It was of little surprise then that the French Government on De Gaulle's instructions, rejected once again the British application, mentioning that Britain would need 'a radical transformation' before any such application would be seriously considered by France. ${ }^{27}$ De Gaulle cited the British deficiency in the balance of payments as well as 'British tradition of obtaining cheap food from all parts of the world' as reasons for French rejection, although geo-strategic reasons could have also been at play. ${ }^{28}$ Australians welcomed the second British failure to enter the EEC, however, political debates on this issue did not stop there. The Government once again did little to comprehensively consider the issue of British EEC entry, focusing instead on regional security matters and the war in Vietnam.

The Labor Party, which was in opposition until 1973, warned of grave consequences for Australian primary industries if the British were to join the EEC even after the second French rejection. A prominent Labor Member of Parliament, Ron Davies, gave a speech to the Parliament in which he explained in profound detail the consequences of the EEC's trade drive in Australia's immediate region. He observed that since the UK's first application in 1962, the Australian dairy industry underwent changes with limited federal government's support, and chartered new markets in the Philippines, Singapore and Malaysia. ${ }^{29}$ Davies warned, however, that Australian primary industries could not compete in the long run with the EEC's protectionism and dumping policies, nor could Australian companies be a match to Europe's multinational giants, such as Nestle, protected by EEC governments and their policies of export subsidies. The situation did not significantly improve even after Britain applied again in 1969, following De Gaulle's resignation. The new government in Paris reversed its position upon the third British EEC application, to the shock and bewilderment of most Australians who were suddenly faced with the harsh reality of losing a major trading partner and export market in particular.

\footnotetext{
26 'Important London sugar talks. Statement by the Acting Prime Minister and Minister for Trade and Industry, Mr. John McEwen', Canberra, 16 June 1967,

http://parlinfo.aph.gov.au/parlInfo/search/display/display.w3p;query=Id\%3A\%22media\%2Fpressrel\%2FHPR10 002970\%22, (accessed online 21 June 2017)

27 '1967: De Gaulle says 'non' to Britain-again', BBC,

http://news.bbc.co.uk/onthisday/hi/dates/stories/november/27/newsid_4187000/4187714.stm (accessed online 21 June 2017)

28 Nesta Roberts, 'Emphatic no by de Gaulle', 29 November 1967, The Guardian,

https://www.theguardian.com/world/1967/nov/28/eu.france (accessed online 21 June 2017)

29 'Processed milk products bounty bill 1968', Hansard, House of the Representatives, 14 November 1968,

http://parlinfo.aph.gov.au/parlInfo/search/display/display.w3p;query=Id\%3A\%22hansard80\%2Fhansardr80\%2 F1968-11-14\%2F0226\%22 (accessed online 21 June 2017)
} 
When Britain joined the EEC under Conservative Prime Minister Edward Heath on 1 January 1973, most Australians felt abandoned, betrayed and isolated. The enlarged EEC was a threat to Australian primary industries, even though Australia and the EEC signed their first agreement under G.A.T.T. auspices in 1968. Although Australians had more than a decade to prepare for the eventuality of the UK succeeding in its intent to join the EEC, it was a profound shock with negative consequences for the Australian economy. The export of Australian butter fell by ninety per cent in the year following the end of the Commonwealth preferential agreements with the UK. In all areas in which Australia previously enjoyed special status under the Commonwealth Imperial Preferences system, such as in the sugar and dairy industries but not limited to them, Australian trade declined. The international oil market crisis only added to Australia's financial troubles. The new Australian Government elected in late 1972 under Labor Party leader Gough Whitlam, began to explore new markets such as the People's Republic of China, which Australia officially recognised and with which Australia entered into trade agreements. Whitlam also dismantled the last remnants of the White Australia immigration policy, ending existing immigration agreements with Great Britain and selected European countries. ${ }^{30}$

It can be argued that the British EEC accession of 1973 was a major political and economic watershed moment for Australia. Continued protectionism by the EEC galvanised the Australian Government, opposition and industry bodies (at state and federal levels) to become more pro-active in international trade. The Whitlam Government agreed on a consultative ministerial framework with the EEC in 1974. The relationship with the UK, however, did not become a thing of the past. Both London and Canberra were well-aware of the need to change the terms of reference of their long-standing and continuing relationship. Careful planning by the Australian Government for UK's EEC entry could have protected Australian interests in Europe better.

\section{The first Brexit referendum and Australian political discourses}

The British Labour Government of Harold Wilson, which was elected in 1974, honoured their electoral promise by holding a national referendum on continued EEC membership in 1975. The referendum split the British cabinet, whilst the opposition's conservatives advocated for a 'yes' vote (to remain in the EEC). ${ }^{31}$ The results were astonishing as 32.8 per cent of the voters opted to leave the EEC, whilst more than double that number, 67.2 per cent, voted for continued membership. ${ }^{32}$ Wilson described the result as a 'historical decision'. ${ }^{33}$ The Australian Government supported a 'yes' vote, with Prime Minister Whitlam stating a month before the referendum that

\footnotetext{
30 'The changing face of modern Australia: 1950s to 1970s', Australian government website, http://www.australia.gov.au/about-australia/australian-story/changing-face-of-modern-australia-1950s-to1970 (accessed online 21 June 2017)

31 '26 April 1975: Labour votes to leave the EEC', $B B C$, no date provided, http://news.bbc.co.uk/onthisday/hi/dates/stories/april/26/newsid_2503000/2503155.stm(accessed online 24 June 2017).

32Vaughne Miller, 'The UK in the European Union: in brief', 15 December 2014, House of Commons Library, http://researchbriefings.files.parliament.uk/documents/SNo7060/SNo7060.pdf (accessed online 24 June 2017) 33 '6 June 1975: UK embraces Europe in referendum', $B B C$, no date provided, June 2017).
} 
there would be no advantage to Australia in Britain withdrawing from the EEC. ${ }^{34}$ Prime Minister Whitlam showed support for his British counterpart throughout the referendum campaign, which stood in stark contrast to his predecessors' attitudes in 1962, 1967 and 1969. Whitlam believed that Wilson's Government truly cared for the Commonwealth nations' interests inside the EEC, and that it was an ally of Australia's inside the Common Market. This was also a time when Australia was about to purchase Western European technology to build uranium enrichment plants and needed British support from within the EEC. ${ }^{35}$ An agreement from EURATOM countries, including the UK, was essential for this to happen. The 'special relationship' between the UK and Australia continued despite the trend of Australian exports suffering quite badly in the immediate years after Britain joined the EEC. If the Australian Government had made preparations early enough for that scenario, it would not have been a disloyal ally but rather a nation that looked after Australian interests in Europe with pragmatic foresight and readiness for major changes in that region which were already in the making. The Australian Government today should draw on the lessons from the 1960s and early 1970 s and prepare better this time around before Brexit negotiations are finalised.

Ahead of the $230^{\text {th }}$ anniversary since the UK's First Fleet arrived in Sydney, the relationship between Australia and Britain, as well as ties with the EU are being reassessed. There are many challenges for Australian commercial interests in Europe, such as what appears to be a disintegrating and reforming EU. ${ }^{36}$ The unprecedented process for Brexit formally began when the British Prime Minister notified the President of the European Council of Britain's intention to leave the European Union in March 2017, invoking Article 50 of the Lisbon Treaty for the first time in its short history. ${ }^{37}$ These negotiations, which can only be tough and cumbersome, need to provide some definitive answers to the question of British separation from the EU after more than four decades since the British joined.

The final settlement of the divorce between London and Brussels will directly affect Australia's relationship with the UK. Ben Wellings argues that it would be against Australia's interests to get caught up in Britain's post-imperial 'fantasies' at the time

34 'Prime Minister's press conference Kingston', press release, 9 May 1975, p. 6,

http://parlinfo.aph.gov.au/parlInfo/search/display/display.w3p;query=Id\%3A\%22media\%2Fpressrel\%2FHPRo7 000317\%22 (accessed online 24 June 2017).

35 'Conferences: 31st Federal Conference of the Australian Labor Party, Terrigal, NSW: Minutes and committee reports', 3 February 1975 ,

http://parlinfo.aph.gov.au/parlInfo/search/display/display.w3p;query=Id\%3A\%22library\%2Fpartypol\%2F15131 79\%22 (accessed online 24 June 2017).

${ }^{36}$ For an in-depth historical overview of Australia's relationship with the European Union, see Nina Markovic, 'Courted by Europe? Advancing Australia's relations with the European Union in the new security environment', Parliamentary Library Research Service, Commonwealth of Australia, 14 July 2009, http://parlinfo.aph.gov.au/parlInfo/search/display/display.w3p;query=Id\%3A\%22library\%2Fprspub\%2F4N4U6 \%22, (accessed online 24 June 2017); Nina Markovic 'Australia's evolving relationship with the European Union: an update', Parliamentary Library Research Service, Commonwealth of Australia, 25 October 2012,

http://parlinfo.aph.gov.au/parlInfo/search/display/display.w3p;query=Id\%3A\%22library\%2Fprspub\%2F200102 $5 \% 22$ (accessed online 24 June 2017), and Nina Markovic, 'Australia's relations with the European Union:

towards a deeper regional engagement', Briefing Book for the $44^{\text {th }}$ Parliament, Parliamentary Library Research Service, Commonwealth of Australia, December 2013,

http://www.aph.gov.au/About_Parliament/Parliamentary_Departments/Parliamentary_Library/pubs/BriefingB ook44p/AustEU (accessed online 24 June 2017).

37 Parliamentary Library's Research Service, 'Brexit: Article 50 and beyond', Commonwealth of Australia, 18 April 2017,

http://www.aph.gov.au/About_Parliament/Parliamentary_Departments/Parliamentary_Library/FlagPost/2017/ April/BrexitArticle_50_and_beyond (accessed online 19 June 2017) For details of the Lisbon Treaty, see Treaty of Lisbon website, http://www.lisbon-treaty.org/wcm/the-lisbon-treaty.html (accessed online 24 June 2017) 
when Australia is ready to commence its long-sought negotiations on an FTA with the European Union. ${ }^{38}$ However, Australia risks becoming embroiled in its own 'fantasies' in the foreign policy realm, and not preparing its citizens once again for a major event in international politics, in this case Brexit. The release of a new Foreign Policy White Paper, promised for mid-2017, has not occurred at the time of this writing. However, the new White Paper (the first since 2003, as opposed to the more regular Defence White Papers) has the potential to provide some clarity and even a roadmap for Australians interested in transforming the nation's relationship with Europe.

\footnotetext{
${ }^{38}$ Ben Wellings, 'As Brexit begins, Australia mustn't get caught up in Britain's post-imperial fantasies', 29 March 2017, The Conversation, https://theconversation.com/as-brexit-begins-australia-mustnt-get-caught-up-inbritains-post-imperial-fantasies-74918 (accessed online 21 June 2017).
} 